\title{
KLÂSİK İSLAM HUKUKU LİTERATÜRÜNDE ANTLAŞMA KAVRAMINI İFADE EDEN KAVRAMLARIN ÇEŞITLILİĞİ
}

\section{$\ddot{O} \mathbf{z}$}

Hasan Doğan*

Hukuk, şahısların birbirleriyle veya kurumlarla olan ilişkilerini düzene sokan kurallar bütününden oluşan bir terim ve ilim alanıdır. Medeniyetlerin, toplumların, dinlerin kendi gelenekleri veya kutsal metinlerini kaynak alan ya da onlardan beslenen çeşitli hukuk sistemleri bulunmaktadır. Büyük bir coğrafyaya nüfuz eden İslam dini hem Kur'ân-1 Kerim hem de $\mathrm{Hz}$. Peygamberin hadisleri 1şığında İslam hukukunun oluşmasına katkı sağlamıştır. Her alt dalında büyük bir literatür çeşitliliği ihtiva eden İslam hukuku kendine has disiplin ve yöntem geliştirmiştir. İslam hukukunun bu özelliğini klasik eserlerden günümüz bilimsel çalışmalarına kadar tüm çalışma alanlarında tespit etmek mümkündür. İslam'ın uluslararası hukuka dair kavram zenginliğinin göstergelerinden biri de antlaşmayı ifade eden kavramlardaki çeşitliliktir. $\mathrm{Bu}$ çalışmada antlaşma konusundaki çeşitli kavramlara yer verilecektir.

Anahtar kelimeler: İslam hukuku, antlaşma, sulh, musâlaha, muâhede.

\section{The Diversity of Concepts That Concerning Concept of Treaty in Classical Islamic Law Literature}

\section{Abstract}

Law is a term and a field of science that consist of set of rules which governing the relations of individuals with each other or with official institutions. Civilizations, societies, religions have their own legal systems that originated with their own traditions or nourished by sacred texts. The Islam religion that penetrates a large geographical area both in the light of Qur'an and in the light of the hadiths of The Prophet has contributed to the formation of Islamic law. Islamic law which includes a large variety of literatures in subbranch has developed its own discipline and method. It is possible to determine this feature of Islamic law in all fields of study from classical works to present scientific works. One of the indicators of Islamic richness in concept of international law is the variety of concepts that express the treaty. This study will be sujected with various concepts of treaty.

Keywords: Islamic law, treaty, peace, reconciliation, oath.

\footnotetext{
* Büyükelçi Dr., e-posta: hasandogan1@gmail.com

Makale Gönderim Tarihi: 29.06.2018

Makale Kabul Tarihi $\quad$ : 30.06 .2018
}

NÜSHA, 2018; (46):175-192 


\section{Giriş}

İslam dünyasının sahip olduğu hukuki birikim ve gücü zamanımıza taşıyamaması, İslam hukukunun ise küresel değişimin gerisinde kalması, günümüze intikal eden hukuk mirasına katkısını ifade edememesi ve bu mirasın oluşumundaki rolün geleceğe yönelik kendisine tanıyacağı misyonu yeterince idrak edememesi büyük bir talihsizliktir. Ellerindeki hukuk sistematiği ile ayırt edici bir konuma sahip olan Müslümanların, hem eser hem de literatür anlamında engin bir hazineye varis oldukları tartışma götürmez bir gerçektir.

Hukuk birikimi açısından çevresindeki coğrafyaya nazaran oldukça sınırlı bir birikime sahip Arap yarımadasında doğan İslam hukukunun diğer alanlarda olduğu gibi uluslararası hukukta da özgün bir literatür geliştirdiği bilinmektedir. Gerek İslam hukukuna kaynaklık eden Kur'ân-1 Kerîm ayetleri ve Hz. Peygamber (SAV)'in sözlerinde, gerekse diğer İslam hukuku metinlerinde uluslararası antlaşmaları ifade eden ve birbirinden farklı anlamlara delalet eden çok sayıda sözcüğe yer verilmiş olmasını, yukarıda anılan gerçeğin altını çizen dikkat çekici bir durum olarak değerlendirmekteyiz. $\mathrm{Bu}$ çerçevede makalemizle bahse konu kavramları açıklayarak bu çeşitliliğin İslam hukukunda ne anlam ifade ettiğini ele almaya çalışmaktayız.

\section{A. Anlaşmayı İfade Eden Terimler}

İslam Hukukunda antlaşma kavramını ifade eden çok sayıda kavram bulunmaktadır. Bunları ve işaret ettikleri anlamları şöyle siralayabiliriz:

\section{Sulh ve Musâlaha (Peace, Reconciliation)}

Kelime olarak sulh Arapça sa-le-ha fiil kökünden türetilmiştir ve bozgunculuğun, fesadın, karşılıklı düşmanlığın ve anlaşmazlığın zıddı olarak iyi olmak, düzelmek, yararlı olmak, tarafların aralarının düzelmesi, savaşın ve düşmanlığın bitmesi anlamlarına gelmektedir. ${ }^{1}$ Sulh, Klasik İslam hukuku eserlerinde sadece uluslararası ilişkilere ait bir kavram olarak karşımız çıkmaz. Özellikle kişiler arasındaki anlaşmazlıkları gideren bir akit; bir taşınmaz mala ait anlaşmazlığ yok eden, çözüm getiren uzlaşı anlamıyla belki daha çok telaffuz edilen bir nitelik arz etmektedir. ${ }^{2}$ Nitekim Hz. Peygamber (SAV)'in de bu sözcüğü kişiler arasında anlaşmazlıkların çözümü ile alakalı bir hadisinde yukarıdaki anlamıyla kullandığg görülmektedir: 
"Helalı haram kilan ve haramı helal kılan sulh dışında Müslümanlar arasinda sulh câizdir."”

Türkçede yaygın olarak kullanılan sulh sözcüğünün barışma, barış, hasımlar arasında husumeti kaldırma, anlaşma, uyuşma, uzlaşma, harpsiz geçen zaman, rahat, huzur, sükun manasında kullanıldığını belirtebiliriz. ${ }^{4}$ Günümüzde sulh, çatışma yaşadığı düşmanı bulunmayan bir milletin durumu ve bir devletin diğer bir devletle normal ve âsude münasebetleri olarak değerlendirilmişse de bu tanım daha sonra yetersiz bulunmuş, sulh kavramının sadece siyasi değil, ekonomik ve sosyal bir mahiyet arz ettiği öne sürülmüştür. ${ }^{5}$

Musâlaha, barış ve barış antlaşması şeklinde anlam verilebilecek, "sulh"ten eylemin karşılıklı biçiminde yapıldığını ortaya koyan fiil kalıbına uygun olarak türetilmiş bir sözcüktür. Genel olarak musâlaha, tarafların barış antlaşması yapması tarafların birbirlerine karşı barış ve sükûn ile yönelmeleri, selamet ve emniyet içinde bulunmaları, kavga veya savaşa son vermeleri, aralarındaki fitne ve fesadı ortadan kaldırmayı ifade etmektedir. ${ }^{6}$

Terim olarak İslam hukukunda sulh ve musâlaha birbirinin yerine kullanılan ve davacı ile davalı ya da taraflar arasındaki anlaşmazlığı, düşmanlığı yok eden, fesat ve fitne sebeplerini gideren anlaşma anlamını taşımaktadır. ${ }^{7}$ Özellikle İslam uluslararası hukuk sisteminde sulh ve musâlaha, savaşa son verip düşmanlığı ortadan kaldıran anlaşma ve uzlaşma olarak tanımlanabilir. ${ }^{8}$

\section{Silm ve Müsâleme (Peace)}

Silm, selâm ve müsâleme, se-li-me fiil kökünden türemiş ve barış olarak Türkçeye çevirebileceğimiz sözcüklerdir. Silm, savaşın zıddı, taraflar arasında barış hali demektir. ${ }^{9}$

Silm ve aynı kökten gelen diğer kelimeler barış ve barış antlaşmasını ifade eden anlamlarda isim veya fiil biçimiyle Kur'ân-1 Kerim'de kullanılmıştır. Örneğin:

"Ey iman edenler, topluca barı̧̧a (silm) giriniz." 10

Silm'in, Medine Sözleşmesi olarak isimlendirilen metinde "Silm, müminler arasinda bir ve tektir. Hiçbir mümin Allah yolunda girişilen bir harpte, diğer müminleri hariç tutarak, bir sulh 
antlaşması akdedemez..."11 ifadesiyle sulh anlamında kullanıldığı görülmektedir. ${ }^{12}$

Müsâleme ise, karşıllklı olarak iyi geçinme, zarar ve ziyan vermeme konusunda söz veriş, dostane ilişki içinde olma, savaşan tarafların savaşı terk amacıyla şartlı ya da şartsız biçimde yaptıkları antlaşma anlamlarına gelmektedir. ${ }^{13}$ Hadis-i şeriflerde de müsâleme bu anlamıyla kullanılmışıır. ${ }^{14}$

Selam ise esenlik, emân, güvenlik, barış şeklinde karşıllk bulabileceğimiz aynı kökten türetilmiş bir diğer kavramdır. ${ }^{15}$ Silm ile ayn anlamda, selam (veya selamet),${ }^{16}$ klasik eserlerde taraflar arası barıştan bahsedilen ve siyasi içerikli bir barış ve barış antlaşmasından ziyade, esenlik dileği, huzur ve rahatı karşılayan, daha geniş olaraksa genel barış durumunu içeren anlamıyla kullanılmıştır. ${ }^{17}$ Buna göre Arapça'da barışın karşıllı̆ı olarak belki de en çok tercih edilen sözcük selam, klasik siyasi ve hukuki bağlamda savaşı sona erdirmek anlamını taşımadığı öne sürülmüsstür. ${ }^{18} \mathrm{Bu}$ çerçevede sulh için savaşı sona erdiren barış ve barış antlaşması; selam içinse savaş halinin zıddı olan barış durumu tanımlarını sunarak sulh ve selamı kavramlarının kullanım alanlarını birbirinden ayırabiliriz.

3. Ahd/Ahit ve Muâhede (Commitment, Promise, Oath, Contract, Treaty, Agreement)

Ahd karş1lklı söz verme, and içme, gözetme, yükümlülük, uyuşma, sözleşme gibi anlamlara gelir ve a-hi-de fiil kökünün mastar halidir. ${ }^{19}$ Klâsik siyasi söylemlerin vazgeçilmez sözcüklerinden biri olan ahit (ahd), yer yer akit (akd) ile aynı anlamda kullanılmıştır. Fakat genelde akit (akd), bireyler arasındaki taahhüt ve sözleşmeler; ahit (ahd) ise siyasi ve devletlerarası ilişkiler için tercih edilmesiyle farklı alanların sözcükleri olmuştur. ${ }^{20}$ Ahit (ahd), kimi metinlerde zimmet, kimi eserlerde ise emân sözcüklerinin yerini almıştır. ${ }^{21}$ Ahit (ahd); yasakları, dokunulmazları gözetmek, vefa göstermek, hürmete riayet, sözleşme, ant içme, yeminleşme gibi anlamlara gelmektedir. ${ }^{22}$ Ahit (ahd)'de hem yemin hem de kesin söz verme anlamlarının bulunduğu gözlemlenmektedir. Bu durumda yemin, ahdin dini tarafını; söz verme ise ahlâki yönünü teşkil eder. ${ }^{2 .}$

Kur'ân-1 Kerim'de ahit (ahd) sözcügünün söz ve sözleşme anlamıyla şöyle kullanıldığını görmekteyiz: 
"Verdiğiniz ahitleri, yaptı̆̆ınız sözleşmeleri yerine getiriniz. Zira verilen ahitte sorumluluk vardır. "24

Ayet-i kerimede sadece uluslararası sözleri değil genel olarak tüm bireylerarası ilişkileri de kapsayan bir derinlik olduğu görülmektedir.

Aynı kökten türeyen muâhede ise ahitleşme, karşılıklı sözleşme, karşıllıklı taahhütte bulunma, savaşan tarafların barış antlaşması yapması; kişi, topluluk ve devlet olarak iki veya daha fazla taraf arasında yapılan ittifak anlamlarına gelmektedir. ${ }^{25}$ Hepsinin taraflar arası barış antlaşmasını karşıladığını söyleyemesek de Kur'ân-1 Kerim'in çok sayıda ayetinde söz verme ve sözleşme anlamıyla ahit (ahd) ve muâhede kavramaları kullanılmıştır. ${ }^{26} \mathrm{Hem}$ ahit (ahd) hem de muâhede yapmak sözcükleri şu ayette bir arada geçmektedir:

"Allah katında canlıların en kötüsü inkârcı olanlardır: Onlar inanmazlar, onlar kendileriyle antlaşma yaptığın (muâhede yaptığın) zaman hiç çekinmeden her defasinda yaptıkları antlaşmayı (ahd) bozan kimselerdir., 27

Hadis-i şeriflerde ise taraflar arası sözleşme ve barış antlaşmalarıyla alakalı olarak ahd, kendisiyle antlaşma yapılan anlamına gelen muâhed ve muâhede sözcüklerine rastlamaktayız:

"Kimin bir toplumla arasında ahd (sözleşme) bulunuyorsa müddeti bitinceye kadar ya da eşit şartlar altında onlara antlaşmayı bozma teklifi yapincaya kadar ona ne bir şey eklesin ne de bir şey eksiltsin,"28

İslam hukukunda muâhed (ehl-i hüdne), zimmî ve müste'minden farklı olarak en genel ifadeyle kendileriyle barış antlaşması yapılmış kişi tanımıyla, bireyin statüsünü ve geleceğini belirleyen, özel bir anlam taşımaktadır. ${ }^{29}$ İslam Hukukunda ahd sözcüğü, ayrıca dar-1 İslam ve dar-1 harp ayrımında ara bir bölge tanımlaması için kullanılmıştır. Dar-1 ahd (dar-1 sulh, dar-1 zimme), statüsü kendisiyle barış yapılmış ülkeler için kullanılmıştır. Bu ülke Müslümanların hâkimiyetini tanımış olmakla beraber iç işlerinde serbesttir; bu ülkenin savunması dışa karşı savunması ise Müslümanların devletinin vazifesidir. ${ }^{30}$ 


\section{Hüdne ve Muhâdene (Truce, Armistice, Ceasefire)}

He-de-ne fiil kökünden türeyen hüdne ve muhâdene, sükûnete erme, sulh yapma, ${ }^{31}$ savaşı birakmak üzere muâhede, ${ }^{32}$ düşman ile belli bir müddet savaşı terk etmek konusunda, bir şey karşılığında ya da karşılıksız antlaşma yapmak anlamına gelmektedir. ${ }^{33}$

Hüdne ve muhâdenede diğer barış antlaşmasını ifade eden sözcüklerden farklı olarak süre sınırlaması ön plana çıkmaktadır. Hüdne ve muhâdene daha çok belirli bir süre savaşı bırakmak için kullanılan bir kavramdır. ${ }^{34}$ Hadis-i şeriflerde de bu şekilde kullanıldığını görüyoruz. ${ }^{35}$

\section{Akd/Akit (Contract, Agreement, Document, Decade)}

Akd (akit) lugatta düğüm vurmak, bir şeyi diğerine kuvvetlice tutturmak, bağlamak şeklinde çevirebileceğimiz a-ka-de fiil kökünden türetilmiş; bina kemeri, ittifak, antlaşma anlamlarının yanı sıra 10-90 arasındaki her bir onluk sayı ve çözmek (el-hall) sözcüğünün zıddı olarak kullanılan bir sözcüktür. ${ }^{36}$ İnsan tasarruflarından biri olarak akd (akit), Mecelle'de "Tarafeynin bir hususu iltizâm ve taahhüt etmeleridir ki îcâb ve kabulün irtibatından ibarettir" şeklinde, inıkâd ise "îcabın, mevzuunda neticesini gösterecek meşrû bir tarzda kabul ile bağlanmasıdır” olarak tarif edilmiştir. $^{38}$

Modern hukukçular ise iki veya daha fazla şahsın (tarafin, iradenin) bir hakkı inşâ, nakil veya sona erdirmek üzere ittifakı, bir hususu karşılıklı iltizam ve taahhüd etmeleri, îcap ve kabulü birbirine bağlamaları olarak tanımlamışlardır ${ }^{39}$. Görüldüğü gibi modern hukukun akdi doğrudan bir ittifak olarak belirlemesine belki hiçbir netice çıkarmayan ve İslam hukukunun batıl olarak nitelediklerini de kapsamasına karşın, İslam hukukçuları açısından akd, sadece iki iradenin ittifakı değil, Şâri'in bu (iradeler arasındaki) ittifakın neticesinde hasıl olduğunu kabul ettiği irtibat (bağ)tır. ${ }^{40}$

Akd, özellikle borçlar hukukunda kullanılan ve bu alanla ilgili çok çeşidi bulunan bir kavramdır. Ancak akit, uluslararası hukukta da hayli rağbet görülmektedir.

Kelime, Kur'an-1 Kerim'de genel olarak verilen sözleri ve yapılan antlaşmaları yerine getirmeye ilişkin bir anlam ile zikredilmiştir:

"Ey iman edenler akitleri(n gereğini) yerine getiriniz. ",4 
İslam'ın ilk dönemlerinde de bu kavram, topluluklar arasındaki sözleşmeler için kullanılmıştır. Bunların en önemlisi belki de Hudeybiye Antlaşması'dır ki buna dair metin şöyle başlamaktadır:

"Bu kitap (vesika) Abdullah oğlu Muhammed ile Amr oğlu Süheyl'in akdettiği bir muâhedenâmedir. "42

\section{Mütâreke (Truce, Armistice, Ceasefire, Cessation)}

Karşılıklı olarak bırakma, terk etme, antlaşmaya gidilmesi ${ }^{43}$ anlamını taşıyan te-ra-ke (terk etmek) fiil kökünden gelen bir sözcüktür. Daha geniş olarak mütâreke, savaşın tarafların muvâfakatı ile barış görüşmelerine başlamak; yaralı toplamak, ölü gömmek gibi sebeplerle silah bırakma, ateş kesilerek savaşın tatil edilmesidir. Buna göre mütâreke, savaşı tümüyle sona erdirmeyip ateşkes antlaşması olarak değerlendirebileceğimiz ve savaşı nihâî olarak sona erdiren barış antlaşmasına imkân tanıyan geçici bir durum meydana getiren antlaşmadır. ${ }^{44}$ Modern hukukta kullanılan karter kavramı, süresi sınırlı mütarekeye işaret eder. ${ }^{45}$

Mütâreke, Kur'ân-1 Kerîm'de hiç kullanılmamıştır; eski ve hatta yeni metinlerde de bu sözcüğe pek rastlanmamaktadır.

\section{Mîsâk (Covenant, Agreement, Contract, Treaty)}

Ve-se-ka Arapça fiil kökünden türeyen mîsâk, sözcük olarak güvenmek, sağlam olmak, sağlam tutmak, sağlama bağlamak gibi anlamlara; kavramı olaraksa bir hususta fikir birliğine varma, yeminleşme, söz verme, ahit (ahd), pekiştirilmiş antlaşma, yemin, peyman, kesin söz almak demektir. ${ }^{46}$ Özellikle son yüzyılda uluslararası hayatın düzenlenmesine ilişkin uyuşma ve uzlaşmalar için bu terimin kullanıldığı görülmektedir. Briand-Kellog, Milletler Cemiyetinin statüsü ve Balkan antlaşmaları için mîsâk sözcügü tercih edilmiştir. $^{47}$

Mîsâk, Kur'ân'da daha çok Allah'ın kullarından aldığg sözü, Allah ile kulları arasındaki antlaşmayı ifade etmek için kullanılmış bir terimdir. ${ }^{48}$

“Onlar (fâsıklar), Allah'a kesin söz verdikten (mîsâk) sonra sözlerinden (ahit) dönerler. Allah'ın birleştirilmesini emrettiğini ayırır ve fesat çıkarırlar. Işste onlar gerçekten zarara uğrayanlardir. "49 
Ancak bu sözcüğe Kur'ân-1 Kerîm'de topluluklar arasındaki sözleşmeleri belirten anlamıyla da yer verildiğini görmekteyiz. Nitekim Kurân-1 Kerîm'de şöyle buyrulmaktadır:

"Ancak sizinle aralarında mîsâk (antlaşma) bulunan bir kavme iltica edenler yahut ne sizinle ne de kendi kavimleriyle savaşmak (istediklerin)den göğ̈̈sleri daralıp size gelenler müstesna... "50

\section{Hılf (Alliance)}

Yardımlaşma, ittifak yapmak için destek olma, dostluk ve bu hususta söz verme, antlaşma gibi anlamlara gelmektedir. ${ }^{51}$

Risaleti öncesinde Hz. Peygamber (SAV)'in bünyesinde yer aldığı, çatısı altında haksızlıklara karşı mücadele verdiği ve İslam'dan sonra da kendisinden övgüyle söz ettiği meşhur erdemliler hareketine bu kavram isim olmuştur. "Hılfu'l-Fudûl'"ün mahiyeti ile ilgili olarak kaynaklarda çeşitli bilgilere rastlamaktayız. Kureyş kabileleri arasındaki çağrı üzerine, Teym b. Merre, Zühre b. Kilâb, Esed b. Abdüluzza, Muttalib oğulları ve Hâşim oğullarının, Abdullah b. Cud'an'ın evinde toplandıklarını; gerek Mekke'de yaşayanların gerekse oraya giren yabancıların zulme uğramamaları ya da uğradıkları takdirde haklarının iadesi hususunda tüm kabilelerin birlikte hareket edeceklerine dair bir antlaşma yaptıklarını ve daha sonra Kureyşlilerin bu antlaşmayı Hılfu'l-Fudûl (faziletler sözleşmesi) olarak isimlendirdiklerini görmekteyiz. ${ }^{52}$

Yine Hz. Peygamber (SAV)'in: “Mutayyibîn antlaşmasina katıldım. Bana kızıl develer dahi verilse bu antlaşmayı bozmak istemem ",53 sözlerinden de anlaşılacağ 1 üzere içinde bulunmaktan ötürü gurur duyduğunu belirttiği ve Hilfu'l-Fudûl'dan farklı olduğu düşünülen ${ }^{54}$ antlaşmada da "hılf" sözcüğü tercih edilmiştir.

\section{Muvâdea}

Muvâdea bir şeyi terketmek, sulh yapmak gibi anlamlara gelmektedir. ${ }^{55}$ Kavram, kendisine benzeyen diğer bazı kavramlarla birlikte geçici süreli antlaşmalardan biri olarak değerlendirilmektedir. ${ }^{56}$ Müslümanlar dar-1 harpten bir topluluk ile ve kendilerine İslam hükümlerinin uygulanmaması kaydiyla antlaşma yaparlarsa, bu topluluğun topraklarına "dâru'l-muvâdaa" adı verilmektedir. ${ }^{57}$ Muvâdea kavramı da Kur'ân-1 Kerim'de bu anlamda kullanılmış değildir. 


\section{Murâveze}

İslam hukukunda bu kavram, daha çok barış görüşmeleri yapmak anlamında kullanılmaktadır. Barışın sağlanması amacıyla gerçekleştirilen diyologlar, müzakereler, murâveze kapsamına girmektedir. ${ }^{58}$ Murâveze kavramına da Kur'ân-1 Kerim'de şahit olmamaktayiz.

\section{Zimmet Anlaşması}

Zimmet bir kimsenin yüklendiği, ödemeye mecbur olduğu borç, alacak; himaye, sahip çıkma; antlaşma, ahit; bu kökten gelen zimmî ise şahsına güvence verilip korumaya alınan kişi anlamlarına gelmektedir. Zimmîler, Müslümanlarla yaptıkları zimmet antlaşması ile cizye ödemek karşılığında İslam ülkesinde vatandaş statüsü ve haklarının korunması güvencesi (zimmet) elde etmektedirler. ${ }^{59}$ Gayrimüslimler, İslam ülkesi ve Müslümanlarla hukuki ilişkileri bakımından dört kısımda değerlendirilmektedir ki bunlar müste'menler, muâhidler, harbîler ile zimmîlerdir. Zimmîler, zimmet anlaşmasından ötürü İslâm devletinin vatandaşı olmak suretiyle diğerlerinden ayrılmaktadır. ${ }^{60}$

Zimmet kelimesi Kur'ân-1 Kerim'de "verilen söz, antlaşma" anlamlarıyla yer almaktadır. ${ }^{61}$ Müslümanların ülkesinde İslamiyet'e girmeksizin yaşamak isteyenlere bu konuda malî sorumluluk yüklenmek ve İslam ahkâmına boyun eğmek suretiyle özgürlük tanınması ilgili ayet-i kerimeye dayanmaktadır. ${ }^{62}$

Zimmîlik statüsü, temelde zimmet antlaşması ile elde edilmektedir. Bunun dışında doğum, evlilik, devlet başkanının af ilanına dayalı olarak cizye uygulaması gibi sebepler de zimmilik statüsü doğurabilir. Keza müste'men statüsüyle İslam ülkesinde bulunan bir gayrimüslimin emân süresi dolmasını müteakiben dönmeyip ikametini sürdürürse ve cizye yükümlülügünü üstlenirse yine zimmî durumuna dönüşür. ${ }^{63}$ Buna benzer karineler de zimmilik statüsünün doğmasına sebebiyet vermektedir.

"Düşmanına ulaştı̆̆ın zaman ona üç seçenek ver. Bunlardan kabul ettiğini sen de kabul et ve ona ilişme. Onlarl önce Müslüman olmaya çağır. Ĕ̆er kabul etmezlerse cizye vermelerini iste, olumlu cevap verirlerse onlara dokunma!",64 
Zimmet antlaşması Müslümanlar için bağlayıcı, gayrimüslimler içinse bağlayıcı değildir. Yani gayrimüslimler dilediklerinde zimmet antlaşmasını bozma, İslam ülkesini terk etme imkânına sahiptir. Buna göre zimmet antlaşması, zimmînin kendi isteğiyle veya şartları ihlali ya da ihaneti suretiyle feshedilebilir. Zimmînin Müslüman olması, zimmet antlaşmasını kendiliğinden nihayete erdirmektedir. ${ }^{65}$

Hz. Peygamber (SAV)'in döneminde çok sayıda zimmet antlaşması akdedilmiştir. Bunlardan Necranlı Hıristiyanlarla yapılan antlaşmada cizye dışında faizli iş yapmamak, elçilerin misafir edilmesi, öşür ödenmemesi, askere alınmama, ihtiyaç halinde zırh, at, deve gibi savaş gereçlerini ödünç vermek, bunların geri verilememesi durumunda bedelinin alınması gibi hususlara yer verilmiştir. $^{66}$

\section{B. Antlaşmayı İfade Eden Kavramlar Arasındaki İlişki}

Antlaşmayı ifade eden kavramların tasnifi ve birbiriyle ilişkisinde süre önemli bir rol oynamaktadır. Bu kavramların bazıları arasında geçicilik etrafında bir anlam yakınlığı dikkat çekmektedir. Süreli antlaşmalara Hudeybiye Antlaşması, süresiz/sürekli antlaşmalara ise Necran, Eyle, Hecer, Bahreyn, Cerbâ ve Ezruh halklarıyla imza edilen antlaşmalar örnek gösterilebilir. ${ }^{67}$

Mütâreke, muvâdea, hüdne (muhâdene) kavramlarının özellikle süreli antlaşmaları ve hatta ateşkes antlaşmalarını ifade ettiği söylenebilir. ${ }^{68}$ Murâveze, bunlara göre daha ön bir aşamayı ifade etmektedir.

Hüdne, üst sınırı on yıl olarak değerlendirilen ve karşı tarafamecburiyet halinde- mal vs vermeye uygun bir antlaşma olarak ele alınmaktadır. Hüdnenin karşı tarafa hiçbir şekilde mal vermeyi olağan hale getirmeyen ve üst sinırı bir yıl kabul edilen ahit kavramından bu şekilde ayrıldığını görmekteyiz. ${ }^{69}$

Esasen muâhede ve musâlaha kavramları da geçici antlaşmalar için kullanılmaktadır. Bu iki kavram neredeyse aynı anlamda kullanılıyorsa da, musâlahanın muâhededen sonra ortaya çıkan bir durum olduğu düşünülmektedir. Buna göre karş1lıklı taahhütlerde bulunarak barış ortamını tesis iradesinin ortaya konmasıyla muâhede; antlaşmanın yürürlüğe girmesiyle de musâlaha gerçekleşmektedir. ${ }^{70}$ 
Devletin ve siyasi otoritenin gayrimüslimlerle yaptığ antlaşmaları dışında, İslam hukuku Müslüman bireylere, mesleki, ticari ve benzeri hususlarda gayrimüslim bireylerle antlaşma yapma ve güvence verme imkânı sağlamıştır. Emân ismi verilen müessese ile Müslüman toprakları ve gayrimüslim ülkesi arasında iletişim ve münasebetler hakkında büyük kolaylı elde edilmiştir. Müslümanların siyasi otoritesinin gayrimüslim vatandaşlara barışçıl ilişki ve birtakım haklar tanımasını belirten ve bir tür sürekli mukavele olarak niteleyebileceğimiz zimmet ile başka gayrimüslimlere inanç ve yaşam hürriyeti temin ettiği görülmektedir.

Öte yandan ahit, tezimizde esas aldığımız barış antlaşması ifadesinden farklı olarak emân kavramı yerine ya da emân kavramına benzer biçimde, bazı metinlerde de zimmet anlamında kullanılmıştır. ${ }^{71}$ Buna göre ahit, Müslümanların ülkesine giren bir gayrimüslime seneyi bulmamak kaydıyla güvence tanımak olarak tanımlanırken $^{72}$ hükmü ve süre sınırlaması taşıyıp taşımaması açısından ahit kavramından farklı olan emân, ahdin tersine Müslümanların emiri ya da nâibi tarafindan değil kişiler tarafindan verilmektedir. ${ }^{73} \mathrm{Bu}$ çerçevede aynı yoruma göre ahit ve hüdne kavramları, Müslümanların başkanı ya da yetkilisi tarafindan gerçekleştirilmesi ve içinde Müslümanlar nâmına maslahat taşıması şartını gerektirmesi bakımından benzerlik taşımaktadır.

Klâsik siyasi söylemlerin vazgeçilmez sözcüklerinden biri olan ahit (ahd), yer yer akit (akd) ile de aynı anlamda kullanılmıştır. Fakat genelde akit, bireyler arasındaki taahhüt ve sözleşmelerde; ahit ise siyasi ve devletlerarası ilişkilerde tercih edilmek suretiyle farklı alanların kelimeleri olmuştur. Ayrıca akit kavramının daha bağlayıcı ve kesin bir anlam ifade ettiği belirtilmektedir. ${ }^{74}$ Buna göre ahit, ilzâm (mecbur kılma), akit ise iltizam yani o mecburiyeti çok sağlam bir şekilde kabul etmektir. ${ }^{75}$ Hukukçular ahdin ya antlaşmanın bozulması ya da tek taraflı feshi veya antlaşma şartlarının İslam hukukuna aykırı olması durumlarında sona ereceği görüşündedirler. ${ }^{76}$

Zimmet antlaşması, sürekli bir antlaşma niteliği taşımaktadır. Ancak itirazlarla beraber kamu otoritesinin yetkisinde olması ve bir yıllık süre sınırına tabi olmaması ile emândan ayrılmaktadır. ${ }^{77}$ 


\section{Sonuç}

Kavram seçimi ve kavram çeşitliliği bilim dallarının derinliğine işaret eden ölçüler arasında değerlendirilmektedir. Hukuk, kavram seçimi ve kullanımında en hassas olunması gereken bilim dallarından biridir. Kullanılan sözcüklerin işaret ettiği anlamlar, konunun doğru algılanması ve isabetli hükme varılabilmesi için büyük önem arz etmektedir.

Kısa zaman içerisinde olgunlaşıp kendine has disiplin, yöntem ve alt dallar geliştiren İslam Hukuku, kavramlar arasındaki farklar ve kavramların birbirleriyle olan ilişkilerinde kendisine mahsus bir çizgi yakalamıştır. İslam hukuku, Hz. Peygamber (SAV) ile birlikte doğmuş ve muhitindeki diğer hukuk sistemlerinden yararlanmakla birlikte özgün biçimde ve süratle gelişme göstermiş bir ilim dalıdır. Müslümanların kısa zamanda çok geniş bir coğrafyaya ve birbirinden çok farklı kültür ve medeniyetlere egemen olması, İslam'ın hukuk sistemini toplumun gerisinde bırakmamış, İslam hukuku üretken yapısı ile çağdaşı tüm hukuk sistemlerinden daha kapsamlı bir duruma erişmiştir.

İslam hukukunun ilk dönemlerinde ortaya konan büyük hacimli eserlerde uluslararası hukuka geniş yer ayrılmış, hemen eş zamanlı olarak da bu alana dair müstakil eserler kaleme alınmaya başlanmıştır. Batı'da uluslararası hukukun mimarı kabul edilen Hugo Grotius ${ }^{78}$ ile aynı alanda İslam hukukunun ilklerine imza atan Ebu Yûsuf ${ }^{79}$ ve Muhammed eş-Şeybânî ${ }^{80}$ (ö. 805) arasında yaklaşık sekiz buçuk yüzyıl bulunmaktadır.

$\mathrm{Bu}$ durumun bir yansıması, İslam Hukukunun devlet veya topluluklar arasındaki uzlaşmayı, antlaşmayı ifade etmek maksadıyla sunduğu terim çeşitliliğidir. Görüldüğü gibi İslam hukuku literatüründe ve dolayısıyla dilimizde uluslararası antlaşmaları ifade eden çok sayıda sözcüğe rastlamaktayız. ${ }^{81}$ Mezkur kelimelerin birbirlerinin yerine kullanıldığ 1 dikkat çekmekteyse de bunlar arasında uzmanların ve konuya ilgi duyanların tespit edebileceği önemli farklar bulunduğu dikkatten kaçmamalıdır. Hukuk disiplin ve nosyonu açısından hayli verimsiz bir coğrafyada doğan İslam Hukuku'nun diğer dallarda olduğu gibi milletler hukuku alanında da kısa zamanda çok sayıda kavram üretmesi ve bunları hukuk literatürüne kazandırması, İslam Hukuku'nun hukuk ilminin gelişim sürecine katkısını ve bu husustaki engin hassasiyetini ortaya 
koymaktadır. Bu çerçevede, günümüz modern hukukunun söz konusu alana ilişkin terminoloji zenginliğini, İslam Hukuku'nun, yüzyıllar öncesinden bu yana bünyesinde barındırdığını söyleyebiliriz.

\section{Kaynakça}

Alsan, Zeki Mesut, Devletler Hukukunda Yeni Gelişmeler, MEB Basimevi, Ankara 1948.

el-Aynî, Bedrüddin Mahmud b. Ahmed, Umdetü'l-Kârî Şerhu Sahîhi'i-Buhârî, Kahire 1328.

Bilmen, Ömer Nasuhi, Hukuki Islâmiyye ve Istılâhâtı Fıkhiyye Kâmusu, Ofset Yetmişbeș Matbaası, İstanbul 1968.

el-Buhârî, Ebû Abdullah Muhammed b. İsmail, el-Câmiu's-Sahîh, Dâru Sahnün-Çağrı yay., İstanbul 1992.

Çalışkan, İbrahim, İslâm Ceza Hukukunda Gayri Müslimlerin Statüsü (basılmamış doktora tezi), Ankara 1986.

ed-Dârimî, Ebû Muhammed Abdullah Abdurrahman, Sunen, Dâru

Sahnûn-Çağrı yay., İstanbul 1992.

Doğan, Mehmet, Büyük Türkçe Sözlük, Eramat Mat., İstanbul 1996.

Ebû Dâvûd, Süleyman b. Eş'as, Sunen, Dâru Sâhnûn-Çağn yay. İstanbul 1992.

Ebu Süleyman, Ahmed, İslâm'ın Uluslararası İlişkiler Kuramı, Acar Matbaacilık, İstanbul 1985.

Ebu Zehra, Muhammed, Alâkâtü'd-Devliyye fi'l-İslam, Dâru Fikri'l-Arabî, Kahire (ty)

Ece, Hüseyin, İslam'ın Temel Kavramlarl, Umut mat., İstanbul 2000.

Gadban, Münir Muhammed, Íslam'da Siyâsî Antlaşma, çev.Asım Kanar, Kerem Mat., İstanbul 1992.

Hamidullah, Muhammed, Íslam'da Devlet İdaresi, çev. Kemal Kuşçu, Gaye Mat, Ankara 1979.

el-Vesâiku's-Siyâsiyye, çev. Vecdi Akyüz, Umut Kağ. Mat., İstanbul (t.y.) 
Heykel, Muhammed Hayr, el-Cihâd ve'l-Kitâl fî̀'s-Siyâseti'şŞer'iyye, Dâru'l-Beyârik, Beyrut 1996.

Hicâzî, Mustafa, el-Mu'cemu'l-Vecîz, Mecmeu'l-Lugati'lArabiyye, Misir $1400 \mathrm{~h}$.

Hırşî, Ebu Abdullah, Şerh-i Muhtasar-i Halîl, (by), Beyrut (ty) İbn Hanbel, Ahmed, el-Müsned, Dâru Sahnûn-Çağrı yay., İstanbul 1992.

İbn Hişâm, Abdülmelik, es-Sîretü'n-Nebeviyye, Matbaatü'sSeniyye, Bulak 1295.

İbn Kudâme, Abdullah b. Ahmed el-Makdîsî, el-Mugnî alâ Muhtasari'l-Hirâkî, Dâru'l-Fikr, Beyrut 1404h.

İbn Manzûr, Ebû'l-Fazl Cemâlüddin Mühammed b. Mükrem, Lisânü'l-Arab, Dâru Sâdır, Beyrut (t.y)

Karaman, Hayrettin, Ana Hatlarlyla İslam Hukuku 3- Hususi Hukuk, Bayrak Matbaacılık, İstanbul 1986.

el-Kâsânî, Alâüddin Ebû Bekir b. Mesûd, Bedâiu's-Sanâi' fî Tertîbi'ş-Şerâi', Matbaatü'l-Cemâliyye, Misır (t.y.). el-Lahaydân, Sâlih, el-Cihâd fî̀-İslâm, Dâru's-Samîî, Riyad 1997.

Lewis, Bernard, İslam'ın Siyasal Söylemi, Kurtiş Matbaası, İstanbul 1993.

el-Mâverdî, Ebû'l-Hasan Ali b. Muhammed b. Habîb el-Basrî el-Bağdâdî, el-Ahkâmu's-Sultaniyye, Dâru'lKitâbi'l-Arabî, Beyrut 1415h.-1994m. el-Hâvî'l-Kebîr fî Fıkhi Mezhebi'l İmâmi'ş-Şâfî̀ ve Hüve Şerhu Muhtasari'l-Müzenî, Dâru'l-Kütübi'lİlmiyye, Beyrut 1414 h., 1994 m.

Mesud Efendi, Mir'ât-ı Mecelle, Âsitane, t.y., y.y.

Müslim, Ebû'l-Huseyn b. el-Haccâc, el-Câmiu's-Sahîh, Dâru Sahnûn-Çağrı yay. İstanbul 1992.

Özel, $\quad$ Ahmet, "Darussulh" Maddesi, DIA, IX.

er-Râzî, Muhammed b. Ömer b. el-Huseyn b. Ali el-Kuraşî eîTeymî el-Bekrî et-Taberistânî Fahruddîn, Mefâtîhu'l Gayb, Matbaatü'l-Âmire, (y.y.) 1308 h.

Sırım, Veli, İslam'ın Nihai Hedefi Evrensel Barış, Ziya Ofset, İstanbul 1999. 
Şafak, Ali, Hukuk Terimleri Sözlügüu, Gümüş Mat., Ankara 1992.

et-Tirmizî, Ebû Îsâ Muhammed b. Îsâ b. Sevra, Sunenu't-Tirmizî, Dâru Sahnûn-Çağrı Yay., İstanbul 1992.

Yaman, $\quad$ Ahmet, “Zimmi” Maddesi, DİA, XLIV.

ez-Zerkâ', Mustafa Ahmed, el-Fıkhu'l-lslâmî fî Sevbihi'I-Cedîdel-Medhalü'l-Fıkhiyyü'l-Âm, Matâbiu Elif Bâ', Dımeşk 1967-1968.

ez-Zuhaylî, Vehbe, Alâkâtü'd-Devliyye fi'l-İslam, Beyrut 1982.

${ }^{1}$ Ebû'l-Fazl Cemâlüddin Muhammed b. Mükrem b. Manzûr, Lisânü'l-Arab, Dâru Sâdır, Beyrut (t.y.), II, 516-517; Mustafa Hicâzî, el-Mu'cemu'lVecîz, Mecmeu'l-Lugati'l-Arabiyye, Misır 1400 h. -1980 m., s. 368.

2 Mecelle-i Ahkâm-1 Adliye, Madde 1531 (Bkz. Mesud Efendi, Mir'at-ı Mecelle, Âsitâne, t.y., y.y., s. 40; Bernard Lewis, Íslam'ın Siyasal Söylemi, Kurtiş Matbaası, İstanbul 1993, s. 94; Hayrettin Karaman, Ana Hatlarıyla İslam Hukuku 3- Hususi Hukuk, Bayrak Matbaacılık, İstanbul 1986, s. 291.

${ }^{3}$ Ebû Îsâ Muhammed b. Îsâ b. Sevra et-Tirmizî, Sunenu't-Tirmizî, Dâru Sahnûn-Çağrı yay., İstanbul 1992 (Ahkâm 17)

${ }^{4}$ Mehmet Doğan, Büyük Türkçe Sözlük, Eramat Mat., İstanbul 1996, s. 1002.

${ }^{5}$ Zeki Mesut, Devletler Hukukunda Yeni Gelişmeler, MEB Basımevi, Ankara 1948, s. 112-113.

${ }^{6}$ İbn Manzûr, II, 517; Ali Şafak, Hukuk Terimleri Sözlüğü, Gümüş Mat., Ankara 1992, s. 357.

7 Bedrüddin Mahmud b. Ahmed el-Aynî, Umdetü'l-Kârî Şerhu Sahîhi'lBuhârî, Kahire 1328, XIII, s. 265.

8 Alâüddin Ebû Bekir b. Mesûd, Bedâiu's-Sanâi' fî Tertîbi'ş-Şerâi', Matbaatü'l-Cemâliyye VII, 108; İbn Manzûr, II, s. 517.

${ }^{9}$ ez-Zuhaylî, s. 655; Hicâzî, s. 319.

${ }^{10}$ Bakara Suresi, 2: 208. Diğer örnekler için bkz. Enfal Suresi 8: 61; Muhammed Suresi, 47: 35.

${ }^{11}$ Medine Vesikası, Madde 17. Bkz. Muhammed Hamidullah, el-Vesâiku'sSiyâsiyye, çev. Vecdi Akyüz, Umut Kağ. Mat., İstanbul (t.y.), s. 67-71.

12 Diğer örnekler için bkz. Diğer örnekler için bkz. et-Tirmizî, (Kitâbu Tefsîri'l-Kur'ân), V, s. 299; Ebû'l-Huseyn b. el-Haccâc Müslim, el- 
Câmiu's-Sahîh, (Kitâbu'l-Cihâd ve's-Siyer), Dâru Sahnûn-Çağrı yay. İstanbul 1992, II, 1442.

${ }^{13}$ ez-Zuhaylî, s. 655; Şafak, s. 380.

14 Örneğin bkz. Ahmed b. Hanbel, el-Müsned, Dâru Sahnûn-Çağrı yay., İstanbul 1992, III, s. 462.

${ }^{15}$ Hicâzî, s. 319.

Müslümanlar Peygamberlerinin işaretlerine dayanarak selamı her türlü kelamdan önce gerçekleştirilmesi gereken bir vecibe olarak görür. Bkz. Ebû Abdullah Muhammed b. İsmail el-Buhârî, el-Câmiu's-Sahîh, Dâru Sahnûn-Çağrı yay., İstanbul 1992, I, 12; et-Tirmizî, V, 59.

16 İbn Manzûr, XII, s. 289.

${ }^{17}$ Lewis, s. 95 ve 96.

${ }^{18}$ Lewis, s. 96.

${ }^{19}$ Şafak, s. 14; Hıcâzî, s. 438.

${ }^{20}$ Veli Sirım, İslam'ın Nihai Hedefi Evrensel Barış, Ziya Ofset, İstanbul 1999, s. 18.

${ }^{21}$ İbn Manzûr, III, 312; Lewis, s. 96.

${ }^{22}$ İbn Manzûr, III, 312; Muhammed Hayr Heykel, el-Cihâd ve'l-Kitâl fî́sSiyâseti'ş-Şer'iyye, Dâru'l-Beyârik, Beyrut 1996, III, 1472; Hicâzî, s. 438; MİA, Milli Eğitim Íslam Ansiklopedisi (İslâm Alemi Tarih, Coğrafya, Etnografya ve Biyografya Lugati), Milli Eğitim Basımevi, (t.y.), (y.y.), I, 156; Doğan, s. 22.

${ }^{23}$ Hüseyin K. Ece, Íslam 'in Temel Kavramlarl, Umut mat., İstanbul 2000, s. 418. Ahdin hükümdar ile yerine atadığı halefi arasındaki antlaşmayı da ifade ettiği görülmektedir. Veliyyü'l-ahd ya da Türkçede daha yaygın kullanımı ile veliahd tabiri söz konusu antlaşmadan doğmaktadır. (Lewis, s. 96.)

${ }^{24}$ İsrâ Suresi, 17: 34

25 Türk Hukuk Lügatı, s. 241; Hicâzî, s. 439; Şafak, s. 342;

26 İsrâ Sûresi, 17: 34. Diğer örnekler için bkz. Enfâl Suresi, 2: 55-56; Nahl Suresi, 16: 91.

${ }^{27}$ Enfâl Suresi 2: 55-56.

28 et-Tirmizî, (Kitâbu's-Siyer), IV, 143; diğger bazı örnekler için bkz. elBuhârî, (Kitâbu'l-Megâzî), V, s. 11 ve 40; Ebû Muhammed Abdullah Abdurrahman ed-Dârimî, Sunen, Dâru Sahnûn-Çağr1 yay., İstanbul 1992, (Kitâbu's-Siyer), II, s. 551; Süleymân b. Eşas Ebû Dâvûd, Sunen, (Kitâbu'l-Cihâd), Dâru Sahnûn-Çağrı yay., İstanbul 1992, III, s. 191.

29 İbrahim Çalışkan, İslâm Ceza Hukukunda Gayri Müslimlerin Statüsü (basılmamış doktora tezi), Ankara 1986, s. 33.

${ }^{30}$ Ebû'l-Hasen Ali b. Muhammed b. Habîb el-Mâverdî, el-Ahkâmu'sSultaniyye, Dâru'l-Kitâbi'l-Arabî, Beyrut 1994, s. 245.

31 İbn Manzûr, XIII, 434; Lewis, s. 94. NÜSHA, 2018; (46):175-192 
el-Kâsânî, VII, s. 108.

33 İbn Kudâme, X, 517; Türk Hukuk Lügatı, s. 134.

34 Ebû'l-Hasen Ali b. Muhammed b. Habîb el-Mâverdî, el-Hâvî'l-Kebîr fî Fıkhi Mezhebi'l Imâmi'ş-Şâfî̀ ve Hüve Şerhu Muhtasari'l-Müzenî, Dâru'l-Kütübi'l-İlmiyye, Beyrut 1414 h., 1994 m., XIV, s. 296; Muhammed Ebû Zehra, Alâkâtü'd-Devliyye fi'l-İslâm, Dâru Fikri'lArabî, Kahire (t.y.), s. 77; Sâlih el-Lahaydân, el-Cihâd fì'l-İslâm, Dâru's-Samîî, Riyad 1997, s. 126; Karaman, Ana Hatlarıla Íslâm Hukuku I, s. 299.

${ }^{35}$ Ebû Dâvûd, (Kitâbu'l-Cihâd), III, s. 211.

36 İbn Manzûr, III, 296; Mustafa Ahmed ez-Zerkâ', el-Fıkhu'l-İslâmî fî Sevbihi'l-Cedîd-el-Medhalü'l-Fıkhiyyü'l-Âm, Matâbiu Elif Bâ', Dımeşk 1967-1968, I, s. 288 ve 291; MİA, I, s. 240; Türk Hukuk Lügatı, s. 10.

${ }^{37}$ Mecelle, Madde 103.

${ }^{38}$ Mecelle, Madde 104.

${ }^{39}$ Türk Hukuk Lügatı, s. 10; ez-Zerkâ', I, s. 245 ve 292.

40 ez-Zerkâ', I, s. 294.

${ }^{41}$ Maide Suresi, 5: 1.

42 Hudeybiye Antlaşması, Madde 1. Rivayetlerde antlaşmadan kitâb olarak söz edilmektedir. Bkz. ed-Dârimî, II, s. 553.

${ }^{43}$ Şafak, s. 389.

44 el-Kâsânî, VII, 108; Türk Hukuk Lügatı, s. 262.

${ }^{45}$ Sirim, s. 33.

${ }^{46}$ Fahruddîn Muhammed b. Ömer b. el-Huseyn b. Ali el-Kuraşî et-Taberistânî er-Râzî, Mefâtîhu'l Gayb, Matbaatü'l-Âmire, 1308 h., (y.y.), III, 86; Heykel, III, 1472; Ece, s. 416; Şafak, s. 338; Doğan, s. 777

${ }^{47}$ Alsan, Yeni Devletler Hukuku, I, s. 585.

${ }^{48}$ A'raf Suresi, 7: 172-173 gibi.

${ }^{49}$ Bakara Suresi, 2: 27.

50 Nisâ Suresi, 4: 90. Mîsâk, millî mücadelemizin temel hedef olarak belirlediği ve son Osmanlı Mebuslar Meclisi'nin 17 Şubat 1920'de hazırladığı tarihî metin için de tercih edilmiş bir sözcüktür. Bkz. Selahattin Tansel, Mondros'tan Mudanya'ya Kadar, Milli Eğitim Basımevi, İstanbul 1991, III, 18. Türkiye Büyük Millet Meclisi, 18 Temmuz 1920 tarihinde yaptığı gizli oturumda "Mîsâk-1 Millî sınırları içindeki milleti ve vatanı kurtarmak için” ant içmiştir. Tansel, s. 170. (TBMM Zabit Ceridesi, II, 335)

${ }^{51}$ Şafak, s. 174; Gadban, s. 11.

52 İbn Hişâm, I, s. 134-135. 
“Hılfu'l-Fudûl” ifadesini, faziletliler antlaşması, erdemliler sözleşmesi olarak çevirmek mümkündür.

53 İbn Hanbel, I, s. 190.

${ }^{54}$ Gadban, s. 22.

55 Ahmet Özel, "Darussulh" Maddesi, DİA, IX, s. 6.

${ }^{56}$ Hamidullah, İslam'da Devlet Iddaresi, s. 405.

57 el-Kâsânî, VII, s. 109.

${ }^{58}$ Hamidullah, Íslam'da Devlet İdaresi, s. 406; Sırım, s. 29.

${ }^{59}$ Ahmet Yaman, "Zimmi” Maddesi, DİA, 2013, XLIV, s. 434-435.

${ }^{60}$ Yaman, "Zimmi” Maddesi, XLIV, s. 434-435.

${ }^{61}$ Tevbe Suresi, 9: 8 ve 10 .

${ }^{62}$ Tevbe Suresi, 9: 29.

${ }^{63}$ Yaman, "Zimmi" Maddesi, XLIV, s. 435.

${ }^{64}$ Buhârî, "Cihâd", s. 102; Müslim, "Cihâd", s. 2, 12; Ebû Dâvûd, "Cihâd", s. 82.

${ }^{65}$ Yaman, "Zimmi” Maddesi, XLIV, s. 435-436.

66 Muhammed Hamidullah, el-Veŝâiķu's-Siyâsiyye, s. 175; Mustafa Fayda, "Zimmî" Maddesi, DİA, 2013, XLIV, s. 429-430.

${ }^{67}$ Yaman, "Zimmi" Maddesi, XLIV, s. 436.

${ }^{68}$ Hamidullah, Íslam'da Devlet İdaresi, s. 405.

69 el-Mâverdî, el-Hâvî'l-Kebîr, XIV, s. 297.

${ }^{70}$ Sirim, s. 20-21.

71 İbn Manzûr, III, 312; Lewis, s. 96.

72 el-Mâverdî, el-Hâvî'l-Kebîr, XIV, s. 296.

73 el-Mâverdî, el-Hâvî'l-Kebîr, XIV, s. 297.

${ }^{74}$ Sirim, s. 18

75 er-Râzî, VIII, 441.

76 Ahmed Ebu Süleyman, İslâm'ın Uluslararası İlişkiler Kuramı, Acar Matbaacılik, İstanbul 1985, s. 38.

77 Yaman, "Zimmi" Maddesi, XLIV, s. 435.

78 “Savaş ve Barış Hukuku” adlı eserini 1625 yılında yayınlamıştır. 1645'te vefat etmiştir

${ }^{79} \mathrm{Bu}$ konudaki müstakil eserinin adı "Kitâbu'l-Harâc"” tır ve 798 yılında vefat etmiştir.

${ }^{80}$ Kitabının ismi “es-Siyerü'l-Kebîr"” dir ve 805 yılında vefat etmiştir.

${ }^{81}$ Ebu Süleyman, s. 38. 